\title{
In the Senate of the United States
}

\section{November 1975}

\begin{abstract}
Sen. Henry Bellmon of Oklahoma introduced the following bills; which were read twice and referred to the Committee on Commerce.
\end{abstract}

\section{S. 2705}

\section{A Bill}

To provide for a study by the Secretary of Commerce of the need for regulation of weather modification activities, the status of current technologies, the extent of coordination and the appropriate responsibility for operations in the field of weather modification, and for other purposes.

Be it enacted by the Senate and House of Representatives of the United States of America in Congress assembled,

\section{Declaration of Purpose}

SEC. 1. It is the policy of the United States (1) to develop, encourage, and implement, through local, State, Federal, and private efforts, a coordinated, comprehensive, and long-range national program of weather modification for the benefit of mankind through precipitation enhancement, protection from severe storms, and certain other weather modification activities, (2) to encourage the use of techniques which have been proven beneficial and to encourage further research to achieve orderly and beneficial uses of weather modification, and (3) to encourage the safeguarding and enhancing of agriculture, water supply, energy sources, and the atmospheric environment. To promote this policy, it is first necessary to assess the present technology, organizational structure, funding, and problems associated with the orderly implementation of the emerging science of weather modification. Based on this assessment, a detailed weather modification policy for the United States must be established. Further legislation in this area should be guided by this detailed weather modification policy.

SEc. 2. There is hereby established within the Department of Commerce a National Weather Modification Commission (hereinafter referred to as the "Commission").

SEc. 3. (a) The Commission shall be composed of nine members to be appointed by the President, not more than two of whom shall be representatives of each of the following categories: the Federal Government, the States, colleges and universities, private industry dealing with weather modification, and private industry or individuals involved in the production of agricultural products or energy. The President shall designate one of the members of the Commission as Chairman. In making such appointments, the President shall appoint individuals who are known for their experience and competence in the fields of weather modification research, operational weather modification, agriculture, agricultural economics, energy development, weather modification law, and social-ecological factors. Not more than five members of the Commission shall be members of the same political party and not more than four members shall be from Government (Federal and State).

(b) Any vacancy in the Commission shall not affect its powers and five members of the Commission shall constitute a quorum.

\section{Duties of the Commission}

SEc. 4. (a) The Commission shall undertake a comprehensive investigation and study of the present state of development of weather modification technology, the problems impeding effective implementation of weather modification, and other related matters. Such a study shall include, but shall not be limited to-

(1) a review of the present and past research efforts to establish the degree of development of operationally useful weather modification technology, particularly as it relates to precipitation enhancement and reduction of damage from severe storms;

(2) a review of research needs in weather modification to establish areas in which more research could be expected to yield the greatest return in terms of operationally useful weather modification technology;

(3) a review of existing studies to establish the probable economic importance to the United States and to individual States in terms of agricultural production, energy, and related economic factors if the present weather modification technology were to be effectively applied;

(4) a review of the legal, social, and ecological implications of expanded and effective research and operational weather modification projects;

(5) a review of the status and any required improvements of legislation regarding regulation of weather modification activities at all levels of government;

(6) a review of the international importance and implications of weather modification activities by the United States including consideration of the potential for use of weather modification for assistance to developing countries which are unable to produce enough food for themselves;

(7) a review of present and past funding for weather modification from all sources to determine the sources and adequacy of funding in the light of the needs of the Nation and the individual States;

(8) a review of the purpose, policy, methods, and funding of the Federal departments and agencies involved in weather modification and a review of the existing inter-agency coordination of weather modification research efforts.

(b) The Commission shall prepare a preliminary report to the President and to the Congress within one year after its organization, followed within six months by a final report which shall amplify the conclusions of the preliminary report. The report shall contain, but shall not be limited to-

(1) a summary of its findings in each of the areas of investigation specified in subsection (a) of this section;

(2) other findings which the Commission feels are pertinent to a consideration of a national policy on weather modification;

(3) a recommended Statement of National Policy on Weather Modification which shall consider (A) the importance of weather modification to the production of agricultural 
products and energy, to other related economic factors, and the international implications in the light of its findings, and (B) the roles of all levels of government, the private sector, and the colleges and universities in research and operational weather modification;

(4) recommendations and justifications for any changes from the present levels of Federal funding for research and operational weather modification considering the returns to the Nation which might reasonably be expected from the funding changes;

(5) recommendations and justifications for any changes in the organization and involvement of Federal departments and agencies in weather modification which may be needed to effectively implement the recommended national policy on weather modification;

(6) recommendations and justifications for any changes in legislation which may be required to implement and regulate weather modification policies along the lines of the national weather modification policy statement.

\section{Powers of the Commission}

SEc. 5. (a) The Commission or, on the authorization of the Commission, any subcommittee or members thereof, may, for the purpose of carrying out the provisions of this Act, hold such hearings, take such testimony, and sit and act at such times and places as the Commission deems advisable. Any member authorized by the Commission may administer oaths or affirmations to witnesses appearing before the Commission or any subcommittee or members thereof.

(b) Each department, agency, and instrumentality of the executive branch of the Government, including independent agencies, is authorized and directed to furnish the Commission such information as the Commission deems necessary to carry out its functions under this Act.

(c) Subject to such rules and regulations as may be adopted by the Commission, the Chairman shall have the power to-

(1) appoint and fix the compensation of an executive director, and such additional staff personnel as he deems necessary, without regard to the provisions of title 5, United States Code, governing appointments in the competitive service, and without regard to the provisions of chapter 51 and subchapter III of chapter 53 of such title relating to classification and General Schedule pay rates, but at rates not in excess of the maximum rate for GS-18 of the General Schedule under section 5332 of such title, and

(2) procure temporary and intermittent services to the same extent as is authorized by section 3109 of title 5, United States Code, but at rates not to exceed $\$ 150$ per day for individuals.

(d) The Commission is authorized to enter into contracts with Federal or State agencies, private firms, institutions, and individuals for the conduct of research or surveys, the preparation of reports, and other activities necessary to the discharge of its duties.

(e) The General Services Administration shall provide administrative services for the Commission on a reimbursable basis.

\section{Compensation of Members}

SEC. 6. Members of the Commission, other than members who are officers or employees of the Federal Government, shall receive compensation at the rate of $\$ 150$ per day for each day they are engaged in the performance of their duties as members of the Commission. All members shall be entitled to reimbursement for travel, subsistence, and other necessary expenses incurred by them in the performance of their duties as members of the Commission.

\section{Definitions}

SEC. 7. As used in this Act-

(1) The term "weather modification" means any artificially produced changes in the composition, behavior, or dynamics of the atmosphere.

(2) The term "atmospheric environment" includes that portion of air and airborne particles surrounding the Earth and bound to the Earth more or less permanently by virtue of gravitational attraction, and includes any resources contained therein.

(3) The term "weather modification activity" means the use of any weather modification apparatus or weather modification agent to attempt any weather modification.

\section{Appropriations Authorized}

SEC. 8. There is hereby authorized to be appropriated such sums as may be necessary, not to exceed a total of $\$ 750,000$ to carry out the provisions of this Act.

\section{Termination}

SEC. 9. On the nineteenth day after the date of submission of its final report to the President and to the Congress, the Commission shall cease to exist.

\section{S. 2706}

A Bill

To authorize and direct the Secretary of Commerce to plan and carry out an experimental research program to determine the feasibility of and the most effective methods for drought prevention and alleviation by weather modification.

Be it enacted by the Senate and House of Representatives of the United States of America in Congress assembled,

\section{Declaration of Purpose}

SEC. 1. The Congress hereby finds and declares that the multi-state nature of climatic and related phenomena, the severe economic hardships experienced as the result of occasional drought and other adverse meteorological conditions, and the existing role and responsibilities of the Federal Government with respect to disaster relief, require appropriate Federal action to assist the States in attempting to prevent or alleviate such actual or potential adverse meteorological conditions. It is therefore the policy of the United States-

(1) to determine the means by which purposeful weather modification can be used to decrease the impact of drought on agriculture, energy resources, water supplies, economic growth, and the general public welfare;

(2) to conduct experimental research into those scientific areas considered most likely to provide operationally useful techniques for drought prevention or alleviation;

(3) to develop operationally useful methods and devices for weather modification;

(4) to transfer weather modification knowledge, as it is developed, to those agencies, States, private companies, or associations who may seek to use the knowledge for the benefit of mankind; and

(5) to assess the economic, social, environmental, and legal impact of an operational weather modification as it is developed. 


\section{Definitions}

SEc. 2. As used in this Act-

(a) The term "Secretary" means the Secretary of Commerce.

(b) The term "weather modification" means any activity performed with the intention of producing artificial changes in the composition, behavior, or dynamics of the atmosphere.

(c) The term "State" includes the several States, the District of Columbia, the Commonwealth of Puerto Rico and any territory or insular possession of the United States.

SEc. 3. (a) The Secretary is authorized and directed to carry out a ten-year experimental research effort to determine the feasibility and define the conditions for decreasing the effects of drought through weather modification. The research program shall cease and a final report to the Congress and the President shall be due ten years after the date of this Act unless an extention is specifically authorized by Congress.

(b) To obtain the benefits of the best available scientific, technical, and operational knowledge and advice in carrying out and evaluating the above program, the Secretary shall appoint an Advisory Board of not more than six persons who possess knowledge and experience in weather modification research or operations, meteorology, agriculture, and other related fields and who are from States where weather modification research or operations are frequently conducted. The Secretary shall appoint members representing the Federal Government, State, or local government and private companies or associations dealing in weather modification research or operations. Not more than two members of the Board shall be employees of the United States. The Secretary shall appoint a Chairman every two years. The Board members shall serve for three-year staggered terms and may not serve more than six years. The Board shall make policy decisions regarding research priorities and shall recommend methods for conduct and evaluation of the research effort. Members of the Board who are not full-time employees of the United States Government, while serving on the business of the Board, may receive compensation at the rate of not more than $\$ 150$ per diem plus their travel expenses, including per diem in lieu of subsistence, as authorized by section 5703 of title 5, United States Code, for individuals in the Government employed intermittently.

(c) The Secretary shall draw upon the capabilities and expertise of other agencies where practical to avoid duplication of efforts.

(d) The Secretary shall insure that the capabilities of the private sector shall be utilized, where appropriate, in the conduct of the field operations and studies in the above experimental program.

(e) The Secretary shall consult with State and local officials representing those areas in which operations may be conducted. The Secretary is authorized to negotiate agreements or contracts with States or local governments to assure continuity of an experimental area during the period of the field operations. As part of the conditions of these agreements, the Secretary may agree to suspend experimental operations during times when the Governor of a State in which research operations are conducted declares that an emergency drought situation exists so that the State or local agencies may conduct operational drought alleviation measures.

(f) During the course of the above program, the Secretary shall establish a mechanism for providing consultation to State and local governments who wish to mount weather modification drought alleviation efforts of their own, so that such efforts may be carried out using the latest scientific information available. (g) The above program shall include the use of adequate safeguards to govern operations during potential or existing hazardous weather conditions and interference with ongoing Federal weather modification projects. Such safeguards shall be reviewed by the Advisory Board and shall be discussed with governmental officials representing the public in areas where the above program will be conducted.

(h) The Secretary shall conduct concurrent studies of the social, environmental, economic, and legal impacts of the use of weather modification for drought alleviation.

(i) The Secretary shall choose one or more experimental sites in regions of the United States in which drought is frequently a major limiting factor for agricultural production and where water supplies for municipal and other uses are often curtailed by drought.

\section{Reports}

SEc. 4. The Secretary shall submit reports annually to the Congress and the President on (1) his progress in developing effective means of drought alleviation or prevention through weather modification, (2) summaries of other related developments on a worldwide scale, (3) his efforts to transfer the latest scientific drought alleviation information to users, (4) the problems facing effective utilization of weather modification for drought alleviation, and (5) his plans to overcome those problems. A final report shall be due ten years after the enactment of this legislation unless an extension of the experimental program is specifically authorized by Congress.

\section{Appropriations Authorized}

There are authorized to be appropriated to carry out the purposes of this section, $\$ 1,500,000$ for the first fiscal year, and such sums as are necessary, not to exceed $\$ 10,000,000$ for each successive fiscal year, to remain available until expended. This authorization is not intended to limit the availability of funds for other weather modification activities carried out by the Secretary.

\section{S. 2707 \\ A Bill}

To authorize the Secretary of Commerce to carry out a program of assistance to States in preventing and alleviating drought emergencies.

Be it enacted by the Senate and House of Representatives of the United States of America in Congress assembled,

That the Congress hereby finds and declares-

(a) that the multistate nature of climatic and related phenomena, the severe economic hardships experienced as the result of occasional drought and other adverse meteorological conditions, and the existing role and responsibilities of the Federal Government with respect to disaster relief, require appropriate Federal action to assist the States in attempting to prevent or alleviate such actual or potential adverse meteorological conditions; and

(b) that although substantial limits and uncertainties still exist with respect to the state of the art of weather modification, the extensive damage and adverse economic impact which may result from drought and other adverse meteorological conditions dictate that the Federal Government provide appropriate assistance to those States that desire to use existing technology to attempt to prevent or alleviate such damaging conditions. 
SEC. 2. Definitions-As used in this Act-

(a) The term "Secretary" means the Secretary of Commerce.

(b) The term "approved State program" means a program developed by a State, or by two or more States jointly, for the prevention or alleviation of drought conditions, which has been approved by the Secretary.

(c) The term "weather modification" means any activity performed with the intention of producing artificial changes in the composition, behavior, or dynamics of the atmosphere.

(d) The term "State" includes the several States, the District of Columbia, the Commonwealth of Puerto Rico and any territory or insular possession of the United States.

SEc. 3. (a) The Secretary, upon application by a State or States, is authorized to provide financial assistance in implementing approved State programs in any area in which it is shown, in accordance with criteria promulgated by the Secretary, that there is a reasonable likelihood or actual existence of drought conditions which could cause damage to crops, lower water supplies, or otherwise cause substantial economic hardship; criteria shall include rainfall, soil moisture conditions, meteorological and hydrological forecasts, and other related factors.

(b) The Secretary may hold public hearings when he deems it appropriate to determine the views of local or near-by interests in considering any application for assistance with respect to a drought alleviation or prevention program. (c) Assistance under this Act shall be made available in the form of financial grants to States or political subdivisions thereof, or organizations approved by the Secretary, for the purpose of assisting and initiating weather modification measures designed to prevent or alleviate drought conditions. The total amount of such grant payments by the Secretary in any fiscal year shall not exceed 50 per centum of the total cost during that period of implementing such drought alleviation or prevention program.

(d) Financial assistance under this Act shall be allocated among the various States in accordance with guidelines established by the Secretary.

SEc. 4. The Secretary is authorized and directed to coordinate with all appropriate Federal and State agencies, and with private firms, institutions, and individuals known to be authorities in the science of weather modification and related fields, in monitoring and evaluating the results of any assistance granted under the provisions of section 3 of this Act.

SEC. 5. The Secretary is authorized to promulgate such rules and regulations as may be necessary to carry out the purposes of this Act.

SEc. 6. There are authorized to be appropriated such sums as may be necessary to carry out the purposes of this Act, not to exceed $\$ 5,000,000$ for each fiscal year, to remain available until expended.

\section{EMPLOYMENT OPPORTUNITIES}

The National Science Foundation is seeking qualified applicants for two-year appointments to the positions of Director, Division of Astronomical Sciences; Director, Division of Atmospheric Sciences; and Director, Division of Ocean Sciences. The incumbents of these positions will be expected to exercise scientific leadership in guiding the administration of the Foundation's support of research in their disciplines, and to play a major role in developing input from the U. S. scientific community in the planning of future Foundation support of research in these fields.

Applicants must be recognized authorities in astronomy, oceanography, or the atmospheric sciences, and must have demonstrated national and international leadership in their field of expertise. The positions will have an initial tenure of two years and carry salaries of $\$ 37,800$ per year. Persons who are in a position to take a two-year leave of absence from their current scientific or science management responsibilities may find these appointments both challenging and interesting.

Those interested in being considered for such positions should forward current resumes to the Assistant Director for Astronomical, Atmospheric, Earth, and Ocean Sciences, National Science Foundation, Washington, D. C. 20550. Applications are being solicited from qualified individuals in the National Science Foundation, the Government, and the scientific community at large. The National Science Foundation is an Equal Employment Opportunity/Affirmative Action employer. 